\title{
Pollination biology and breeding system of syntopic Adenocalymma nodosum and $A$. peregrinum (Bignonieae, Bignoniaceae) in the Brazilian savanna
}

\author{
Diana S. Sampaio ${ }^{a}$, Clesnan Mendes-Rodrigues ${ }^{a}$, Thaíssa B.J. Engel ${ }^{\mathrm{b}}$, Tiago M. Rezende ${ }^{\mathrm{c}}$, \\ Nelson S. Bittencourt-Jr ${ }^{\mathrm{d}}$, Paulo Eugênio Oliveira ${ }^{\mathrm{a}, *}$ \\ a Universidade Federal de Uberlândia, Campus Umuarama, Bloco 2D, Instituto de Biologia, 38405-320, Uberlândia, Minas Gerais, Brazil \\ b Universidade Estadual de Campinas, Instituto de Biologia, Programa de Pós-Graduação em Biologia Vegetal, 13083-970, Campinas, São Paulo, Brazil \\ ${ }^{\mathrm{c}}$ Instituto Chico Mendes de Conservação da Biodiversidade - ICMBio, EQSW 103/104, Bloco A, Complexo Administrativo, Setor Sudoeste, 70670-350, \\ Brasília, Distrito Federal, Brazil \\ 'Universidade Estadual Paulista “Júlio de Mesquita Filho", Campus São José do Rio Preto, Departamento de Zoologia e Botânica, Rua Cristóvão Colombo, \\ 2265, Jardim Nazareth, São José do Rio Preto, 15054-000, São Paulo, Brazil
}

\section{A R T I C L E I N F O}

\section{Article history:}

Received 16 November 2015

Received in revised form 1 April 2016

Accepted 15 April 2016

Edited by Stefan Dötterl

Available online 20 April 2016

\section{Keywords:}

Cerrado

Interspecific compatibility

Late-acting self-incompatibility

Synchronopatry

\begin{abstract}
A B S T R A C T
The tropical Bignoniaceae is mostly late-acting self-incompatible (LSI) and depends on a guild of medium to large sized bees for their pollination. Adenocalymma nodosum and A. peregrinum are syntopic shrubs in savanna areas with similar flowers and flowering overlap. In this sense, the aims of the present study were to analyse the pollination biology and breeding systems of these species, and to check for bilateral compatibility which could hinder reproductive isolation and species boundaries. Flower features such as yellow corolla, sweet scent and diurnal one-day anthesis were similar between species. However, they differed in nectar production patterns, which showed higher volume in A. nodosum and was irregular in A. peregrinum. The main pollinators for both species were medium to large Centridini bees. Many nectar and pollen robbers may disturb effective pollination and help to explain the low natural fruit-set. The species were self-sterile but pollen tube growth down to the ovules and differential ovary development indicated LSI, as in most Bignoniaceae studied to date, which reinforce the idea of family clustering for this self-incompatibility system. Fruit-set from interspecific hand pollinations was similar to those of intraspecific cross-pollinations, with high seed viability (88\%) and seedling development. Similar floral biology and guild of pollinators, and bilateral inter-compatibility indicate that natural hybridization is possible among these species.
\end{abstract}

(c) 2016 Elsevier GmbH. All rights reserved.

\section{Introduction}

Self-sterility mechanisms are important for co-sexual flowering plants in order to avoid inbreeding and assure adequate pollen flow (e.g. Neuffer and Paetsch, 2013). The Bignoniaceae is considered predominantly self-sterile (e.g. Gibbs, 1990; Gibbs and Bianchi, 1993, 1999; Bittencourt and Semir, 2005, 2006; Gandolphi and Bittencourt, 2010; Bittencourt et al., 2011). Among the 58 species investigated for breeding systems, 49 are self-sterile and nine are self-fertile, but seven species described as self-sterile also show self-fertile populations. In this sense, self-fertility was found in 16 species (Bittencourt and Moraes, 2010; Firetti-Leggieri et al., 2013;

\footnotetext{
* Corresponding author.

E-mail address: poliveira@ufu.br (P. Eugênio Oliveira).
}

Sampaio et al., 2013; Alves in press). It seems that self-fertility has evolved independently in the tribe Tecomeae, Tabebuia Alliance, and Bignonieae clades (sensu Olmstead et al., 2009), and the presence of more than one kind of breeding system in a single species was recorded in the latter two clades.

Among the self-sterile species of Bignoniaceae, 34 have postpollination events studied. These investigations show that the self-pollen tubes grow to the ovary, penetrate and fertilize ovules, which are able to develop an initial endosperm and a proembryonal tube with two nuclei (e.g. Gibbs, 1990; Gibbs and Bianchi, 1993, 1999; Bittencourt and Semir, 2005, 2006; Gandolphi and Bittencourt, 2010; Bittencourt et al., 2011). Those aspects correspond to a late-acting self-incompatibility system, LSI (Seavey and Bawa, 1986; Bittencourt et al., 2003; Gibbs, 2014), which is commonly neglect due to its similarity to early inbreeding depression, especially in cases like those observed in Bignoniaceae where rejection 
of selfed pistils is predominantly post-zygotic (Gibbs, 2014). The facts that LSI shows family clustering, that in Bignoniaceae it is the unique self-incompatibility system (SI) described until now, and that the endosperm and proembryonal tube do not present any malfunction in self-fertilized ovules, are strong arguments for the acceptance of LSI (Bittencourt et al., 2003; Gibbs, 2014). The investigation of the breeding system of a higher number of species of Bignoniaceae will help to understand its evolution in the group, and to reinforce LSI as a genetic controlled SI.

Bignoniaceae shows a high diversity within communities, with up to 20 species per area, and $75 \%$ of species are pollinated by bees (Gentry, 1976, 1980, 1990). Medium and large sized Centridini and Euglossini bees are the most important pollinators (Ynagizawa and Maimoni-Rodella, 2007; Guimarães et al., 2008; Milet-Pinheiro and Schlindwein, 2009; Almeida-Soares et al., 2010). These bees are capable of flying long distances, enabling the occurrence of crosspollinations (Gottsberger and Silberbauer-Gottsberber, 2006), but also the occurrence of interspecific pollination. On the other hand, the great diversity of floral morphology, flowering phenology and seasonality of Bignoniaceae species in a given community (Gentry, 1974b) avoid competition for pollinators and maintain reproductive isolation among congeners (Gentry, 1976, 1980; Amaral, 1992; Ynagizawa and Maimoni-Rodella, 2007; Zjhra, 2008).

There are only two Adenocalymma species already studied for their pollination biology and breeding system, A. marginatum (Cham.) DC. and A. bracteatum (Cham.) DC., both described with LSI (Amaral, 1992), though the later species was recently reported as self-fertile (Almeida-Soares et al., 2010). Adenocalymma nodosum (Silva Manso) L. Lohmann and A. peregrinum (Miers) L. Lohmann are closely related species of shrubs from Cerrado, the Neotropical savanna region in Central Brazil (Lohmann and Taylor, 2014). These species were previously placed in the genus Memora, which was recently found to be nested inside Adenocalymma as a monophyletic group of species (Lohmann, 2006; Lohmann and Taylor, 2014). There are no data available about pollination biology and breeding system for species of the "Memora clade" of the genus Adenocalymma. In Uberlândia, Minas Gerais State, A. nodosum and A. peregrinum are syntopic, and although their flowering seasons usually differ (A. peregrinum flowers from December to April and A. nodosum from March to June) and may function as a reproductive barrier among these species, some flowering overlap has been observed (D. Sampaio, personal observations).

As the "Memora clade" has not been evaluated and more than one kind of breeding system was recorded for A. bracteatum, we investigated the flower biology, pollination, and breeding system of $A$. nodosum and A. peregrinum in order to understand the reproductive ecology of these species and to contribute to the knowledge of breeding system evolution in Bignoniaceae. Finally, since these species occur in syntopic populations with flowering overlap, we tested for inter-compatibility, which can affect reproductive isolation and species boundaries.

\section{Materials and methods}

\subsection{Studied species and study sites}

Adenocalymma nodosum is a caespitose shrub with flexible branches up to $2 \mathrm{~m}$ high. Its leaves are petiolate, bi or tripinnate and imparipinnate (Fig. 1A, B). Leaflets are narrow and lanceolate, sessile when simple, and petiolate when they are compound leaflets (Fig. 1A, B). Flowers arise in the axils of bracts. Bracteoles are also present and the flower pedicel is short, with a mean length of $0.67 \mathrm{~cm}(S D \pm 0.15 ; n=15)$. The calyx tube is green with five lobes. It bears nectaries and glandular trichomes that make it sticky (Fig. 1C, D). The corolla (Fig. 1A, E) is golden yellow and glabrous. The pollen grains are yellow when observed by the naked eye. The staminode is inconspicuous (Fig. 1E), but in some individuals it shows a developed anther with pollen grains. Usually, the style rises the stigma above the stamens (Fig. 1E), but occasionally it lies below the stamen level, favouring spontaneous self-pollination. The flower has a sweet scent and produces nectar on a disk in the ovary base. The fruit is a septicide capsule dorsi-ventrally flattened (Fig. 1F) with active nectaries and glandular trichomes when immature, similar to those found in the calyx tube. Fruits reach maturity in three to four months after pollination. The species occurs in Brazilian States of Mato Grosso, Goiás, Minas Gerais, Rio de Janeiro, Tocantins and Piauí (Lohmann, 2010a).

Adenocalymma peregrinum is also a caespitose shrub up to $1 \mathrm{~m}$ high. The leaves are petiolate, have two or three leaflets or can also be pinnate or bipinnate (Fig. $1 \mathrm{G}-\mathrm{J}$ ). When bipinnate, only the basal leaflets are compound (Fig. 1I). They can be paripinnate or imparipinnate. Leaflets are ovate, sessile when simple and petiolate when compound (Fig. 1G-J). The mean length of the flower pedicel is $1.64 \mathrm{~cm}(\mathrm{SD} \pm 0.26 ; \mathrm{n}=15)$. The calyx is light green and during the corolla emission it breaks, forming one or two longitudinal slits, which make the calyx spathaceous or bilabiate with irregular edges (Fig. 1G, K, L). Calyx and fruit show sparse lepidote trichomes, being almost glabrous and without nectaries (Fig. 1L, M). The pollen grains are white when observed by the naked eye. Other features are similar of those described for A. nodosum. The species occurs in Brazilian States of Mato Grosso, Goiás, Minas Gerais, Rio de Janeiro, Mato Grosso do Sul, São Paulo and Paraná (Lohmann, 2010b). Adenocalymma peregrinum is considered an important invasive species of pastures (Nunes, 1999, 2001; Grassi et al., 2005).

Both species present hemixyle habit, re-sprouting from belowground structures each year, after fire or pruning (Gottsberger and Silberbauer-Gottsberger, 2006). Thus, it was often difficult to define individuals since a cluster of plants may contain sprouts (ramets) from different genetic origins.

Fieldwork was carried out from 2006 to 2009 in campo sujo areas, a plant formation of scattered shrubs on a grassland matrix common in the Cerrado region (Oliveira-Filho and Ratter, 2002). The main area was at the edge of the Clube de Caça e Pesca Itororó de Uberlândia preservation area (CCPIU) (18 58'48.5”S, $\left.48^{\circ} 17^{\prime} 45.8^{\prime \prime} \mathrm{W}\right)$, where the two species are syntopic. Complementary studies were done also at Campo Alegre farm ( $18^{\circ} 58^{\prime} 43.83^{\prime \prime} \mathrm{S}$, $48^{\circ} 14^{\prime} 59.73^{\prime \prime} \mathrm{W}$ ), where only A. peregrinum occurs in another campo sujo used as pastureland. The Campo Alegre farm is $5 \mathrm{~km}$ away from the CCPIU area, and both are in the outskirts of Uberlândia, Minas Gerais State, Brazil. The vouchers were deposited in Herbarium Uberlandense-HUFU, Uberlândia, Minas Gerais State, Brazil, under registration numbers: HUFU 45287 for $A$. nodosum, and HUFU 44908, 48925 - CCPIU, and HUFU 47293 - Campo Alegre farm, for A. peregrinum.

\subsection{Floral biology}

In $A$. nodosum, 47 floral buds in pre-anthesis were bagged in 10 clusters of plants at CCPIU and, in A. peregrinum, 10 buds in pre-anthesis were bagged in five clusters at Campo Alegre farm. Duration of anthesis, beginning of nectar and scent production, stigmatic sensitivity, pollen presentation and anther color were observed in the resulting flowers. Stigmatic sensitivity was tested by touching the stigma lobes with tweezers, and it was considered sensitive if the two lobes closed after being touched.

To estimate pollen viability (based on stainability and form) ten and nine floral buds at the day before anthesis were collected, respectively, from five clusters of plants of $A$. nodosum and five clusters of $A$. peregrinum at CCPIU, and fixed in ethanol 70\%. Slides were mounted with the pollen grains of one anther of each flower, a drop of aceto-carmine, and a drop of glycerol 50\% (Dafni et al., 2005). The 


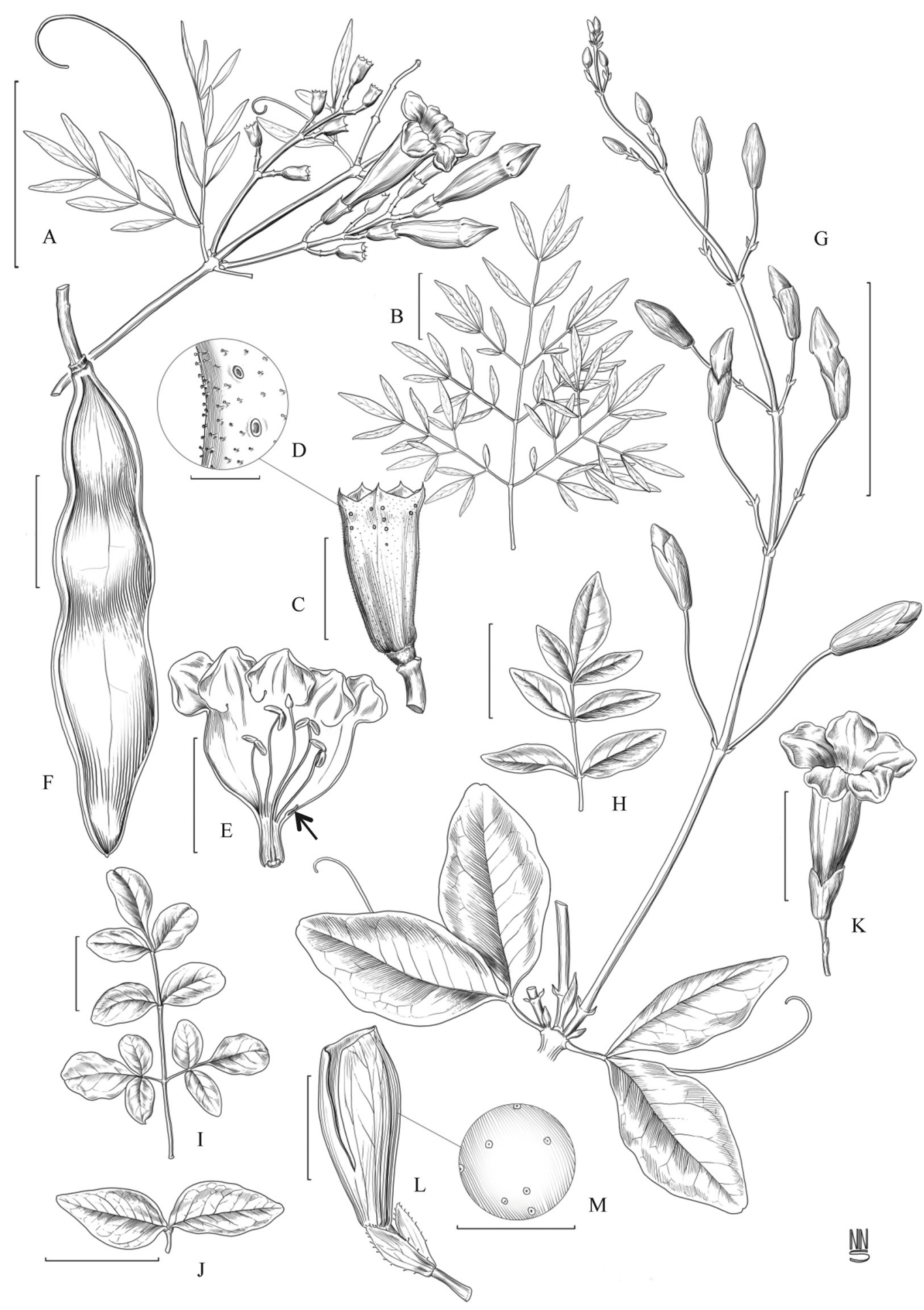

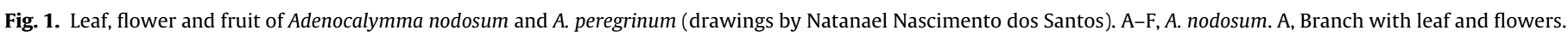

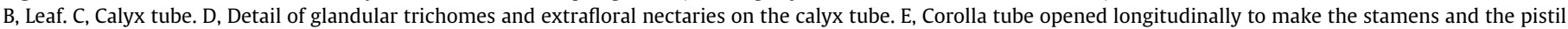

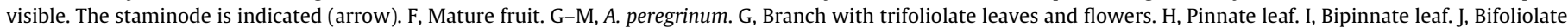

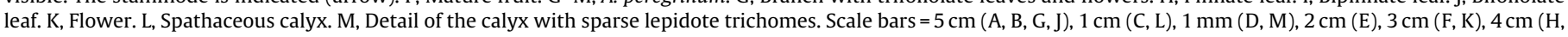
I).

analysis was done using an optical microscope Olympus BX51 and 300 pollen grains were analysed per slide. Pollen grains reduced in size, without cytoplasm, or microspores that were still enclosed in tetrads were considered non-viable.

In order to establish the pollen/ovule ratio, the number of pollen grains per flower was estimated and the number of ovules per ovary was counted (Cruden, 1977). To estimate the number of pollen grains per flower, 16 pre-anthesis buds (i.e., collected a day before flower opening) from eight clusters of plants of $A$. nodosum and 10 pre-anthesis buds from six clusters of $A$. peregrinum were collected at CCPIU, and stored in ethanol 70\%. The pollen grains of two anthers were diluted in $1 \mathrm{ml}$ of glycerol $50 \%$ and the number of pollen grains was estimated in a Neubauer Chamber (Dafni et al., 2005) under optical microscope Olympus BX51. The counting of 
ovules per ovary was performed under a stereomicroscope Olympus SZX12 in 116 dissected ovaries from five clusters of plants of $A$. nodosum and in 113 ovaries from nine clusters of $A$. peregrinum collected at CCPIU. Whenever necessary, parameters were compared between species using Student $t$-test for heterogeneous variances (Zar, 2010).

To analyse nectar features, 36 buds in pre-anthesis for each species from five clusters of plants of $A$. nodosum and from nine clusters of $A$. peregrinum were bagged at CCPIU. During the first day of anthesis, nectar was measured in three time intervals (10:00 h, 13:30 h, 16:30 h) using different flowers per interval. We used $10 \mu \mathrm{l}$ micropipettes to estimate the amount of accumulated nectar, and a handheld refractometer (Eclipse - scale of $1 \%$ ) to estimate nectar concentration of soluble sugars (Kearns and Inouye, 1993). Flowers without nectar and/or damaged were not included in statistical analysis because they presented some damage in the base of the calyx and in the nectary that was probably done before bagging. Nectar data for A. nodosum were analysed using a one-way ANOVA for volume and another one for concentration, after confirming normality for the residuals using Shapiro-Wilk test and homogeneity of variance with Levene test at significance level of 0.05 . The means were compared pairwise with Tukey test, and the data of volume were $\log _{10}$ transformed before statistical analyses. In order to compare nectar features in A. peregrinum, we used a Mann-Whitney test for volume due to absence of normality for each interval. Since concentration data showed normality in each group, we used a Student $t$-test to compare intervals. The normality was tested with ShapiroWilk test. We performed the analyses separately for each species because some of the $A$. peregrinum flowers did not present nectar in the third interval of analysis. The analyses were carried out using SPSS 17.0 (SPSS, Inc., Chicago, IL, USA).

\subsection{Floral visitors}

The floral visitors' study was performed on 10 clusters of plants of $A$. nodosum at CCPIU during nine days in April of 2006, a total of $29 \mathrm{~h}$ and $15 \mathrm{~min}$ of observation. In $A$. peregrinum, we studied 22 clusters of plants at Campo Alegre farm during eight days in January of 2007, a total of $20 \mathrm{~h}$ and 19 min of observation. The observations were done from $8: 00 \mathrm{~h}$ to $17: 00 \mathrm{~h}$, alternating the time of observation among the clusters of plants.

Bee's behaviour and number of visits per flower were recorded and the visitation frequency was calculated (number of visits per hour). Bees that did not enter the corolla tube, but did a perforation in its base (or even use perforations that already existed) to get nectar was considered nectar robbers. Small sized bees that entered the corolla tube to get pollen or nectar were considered pollen or nectar robbers, respectively. Those small sized bees can damage the corolla tube in pre-anthesis buds to get pollen or nectar, or enter the corolla during anthesis causing no damage. Even when they entered the corolla tube they seldom touched the stigma. Medium or large sized bees that entered the corolla tube searching for nectar and contacted the stigma and the anthers during these visits were considered effective pollinators.

Only the first individual of each bee species observed was collected and pinned. After identified, those individuals were taken to the field and used as material for comparison with the following visitors, which were captured, identified, and released in the field. After some training, most species could be identified in the field. The pinned visitors were incorporated to the entomological collection of Instituto de Biologia of Universidade Federal de Uberlândia.

\subsection{Breeding system and interspecific pollination}

As it was often difficult to define individuals for both species, we studied more or less isolated clusters of plants, whereas the number of ramets per cluster varied from three to 21 for $A$. nodosum, and from eight to 21 for $A$. peregrinum at CCPIU. At least 28 clusters of plants of the latter species were also studied at Campo Alegre farm in 2007. Due to the possiblity that a cluster is made of different individuals, we used flowers as sample units and tried to keep the number of flowers used for the experiments similar among the clusters. We also brought pollen for cross-pollination from a safe distance to avoid the use of ramets as different individuals. Numbers of flowers used in each treatment are presented in the results (see Table 3). Flower buds were bagged with nylon mesh to exclude pollinators and other floral visitors. Self- and crosshand pollinations were carried out in first-day flowers emasculated early the day, before pollen was released. In self-pollinations, we used the pollen grains of the same flower. In cross-pollinations and interspecific pollinations we used pollen from clearly distinct clusters of plants at least ten meters away and from clusters of plants of the other species, respectively. Bagged buds were marked to check for spontaneous self-pollination and others were emasculated before isolation to check for autonomous apomixis (for numbers, see Table 3). Natural fruit set was estimated by monitoring marked, non-bagged flowers. The self-incompatibility index (ISI) was determined as the ratio of hand self-pollination/crosspollination fruit-set (Bullock, 1985). The ratio of natural/hand cross-pollination fruit-set was also determined as an estimate of reproductive efficacy (RE) (Ruiz and Arroyo, 1978).

In situ pollen tube growth was analysed to verify if the selfpollen tubes reach the ovary and penetrate ovules as an indication of the presence of LSI in the case of self-sterile species. Pistils from hand self- and cross-pollinations were collected $24 \mathrm{~h}$ after pollination and stored in ethanol $70 \%$. Six pistils per treatment were collected in A. nodosum, and five pistils per treatment were collected in A. peregrinum in five clusters of plants of each species at CCPIU. The ovary wall was removed to expose the ovules. Pistils were softened in $9 \mathrm{M} \mathrm{NaOH}$ solution at $55^{\circ} \mathrm{C}$ for $15 \mathrm{~min}$, washed in flowing water, and stained with aniline blue (adapted from Martin, 1959). The pistils were analysed under optical microscope Zeiss Axioscop equipped with epi-fluorescence.

In order to verify if self-pollinated pistils showed ovary expansion before being aborted, and if this expansion differed from the expansion observed in ovaries of cross-pollinated pistils, we took measurements of ovary length and width. Unpollinated pistils were used as a control group. Measurements of ovary length and width from hand self- and cross-pollinated pistils collected 24, 48, 72, 96 and $120 \mathrm{~h}$ after pollination and of ovaries of unpollinated pistils from emasculated flowers collected 24, 48, 72, 96 and $120 \mathrm{~h}$ after the onset of anthesis were carried out with digital calliper Digimess $\left(300 \mathrm{~mm} / 12^{\prime}-0.01\right)$. Five to ten pistils were measured per treatment and per time interval in A. nodosum and four to eight pistils in $A$. peregrinum collected from five clusters of plants of each species at CCPIU. All pistils were fixed in a $1 \%$ glutaraldehyde plus 4\% formaldehyde solution (McDowell and Trump, 1976) in sodium phosphate buffer $0.1 \mathrm{M}, \mathrm{pH} 7.2$ before measurements. In order to check if there was any growth in ovaries along the time intervals, and if there were differences in growth rates among pollination treatments, we calculated the area of the ovaries (estimated by: area $=$ length $\times$ width). Although robust, data for ovary area did not fit the assumptions for ANOVA analyses (normality from residual and homogeneity of variances) and we therefore used Generalized Linear Models with Gaussian distribution. For main level post hoc comparisons of the pollination treatments we used the Least Significant Difference test and the time intervals were adjusted to polynomial models of different orders whenever necessary. The GLM was performed separately to each species. As for both species the interactions were statistically significant, we performed a GLM for time interval comparisons for each pollination treatment independently and separately for each species, and for 
Table 1

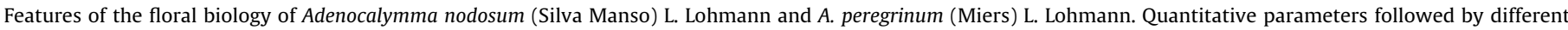
letters differed significantly between species (Student- $t$ test for heterogeneous variance, $P<0.01$ ).

\begin{tabular}{|c|c|c|}
\hline Features & Adenocalymma nodosum & Adenocalymma peregrinum \\
\hline Corolla opening & $7: 00-10: 00 \mathrm{~h}$ & $8: 00-10: 00 \mathrm{~h}$ \\
\hline Scent production & From 9:00 $\mathrm{h}$ to the end of anthesis & From $10: 00 \mathrm{~h}$ to the end of anthesis \\
\hline Nectar production & Before $7: 00$ to $17: 00 \mathrm{~h}$ & Before $8: 00$ to $17: 00 \mathrm{~h}$ \\
\hline Stigmatic sensitivity & Since the pre-anthesis & Since the pre-anthesis \\
\hline Pollen presentation & From 9:00 h & From 9:00 h \\
\hline Darkening of the anthers & From 14:00 h & From $13: 30 \mathrm{~h}$ \\
\hline Duration of anthesis & About $24 \mathrm{~h}$ & About $24 \mathrm{~h}$ \\
\hline Pollen viability\% ( \pm DP) & $95.5( \pm 2.9) \mathrm{a}$ & $77.8( \pm 6.7) \mathrm{b}$ \\
\hline Mean number of pollen grains per flower $( \pm \mathrm{DP})$ & $41750( \pm 29896.5) b$ & $64666( \pm 13185.9)$ a \\
\hline Mean number of ovules per ovary $( \pm \mathrm{DP})$ & $10.0( \pm 3.4) b$ & $14.1( \pm 2.5) \mathrm{a}$ \\
\hline Pollen/ovule ratio & 4175.0 & 4599.3 \\
\hline
\end{tabular}

Table 2

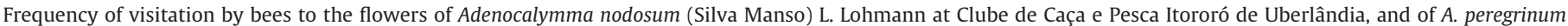
(Miers) L. Lohmann at Campo Alegre farm, both in Uberlândia City, Minas Gerais State, Brazil.

\begin{tabular}{|c|c|c|c|c|}
\hline \multirow[t]{2}{*}{ Species } & & \multirow[t]{2}{*}{ Behaviour } & \multicolumn{2}{|c|}{ Number of visits per hour (Total number of visits) } \\
\hline & & & $\begin{array}{l}\text { Adenocalymma } \\
\text { nodosum (total } \\
29 \text { h } 15 \mathrm{~min} \text { ) }\end{array}$ & $\begin{array}{l}\text { Adenocalymma } \\
\text { peregrinum (total } \\
20 \mathrm{~h} 19 \mathrm{~min} \text { ) }\end{array}$ \\
\hline \multicolumn{5}{|l|}{ Andrenidae } \\
\hline & Oxaea flavescens Klug, 1807 & NR & $3.56(104)$ & $55.31(1124)$ \\
\hline \multicolumn{5}{|l|}{ Apidae } \\
\hline Apini & Apis mellifera Linnaeus, 1758 & PR & $1.40(41)$ & $0.05(1)$ \\
\hline \multirow[t]{7}{*}{ Centridini } & Centris (Centris) aenea Lepeletier, 1841 & $\mathrm{EP}$ & $0.07(2)$ & - \\
\hline & Centris (Trachina) fuscata Lepeletier, 1841 & $\mathrm{EP}$ & $1.91(56)$ & - \\
\hline & Centris (Hemisiella) tarsata Smith, 1874 & $\mathrm{EP}$ & $0.38(11)$ & - \\
\hline & Centris (Heterocentris) analis Fabricius, 1804 & $\mathrm{EP}$ & $0.17(5)$ & - \\
\hline & Epicharis (Epicharis) bicolor Smith, 1874 & $\mathrm{EP}$ & $0.17(5)$ & $0.39(8)$ \\
\hline & Epicharis (Epicharana) flava Friese, 1900 & EP & - & $0.05(1)$ \\
\hline & Centridini sp. 1 & $\mathrm{EP}$ & - & $0.10(2)$ \\
\hline \multirow[t]{2}{*}{ Emphorini } & Alepidoscelis imitatrix Schrottky, 1909 & PR & $0.14(4)$ & $0.15(3)$ \\
\hline & Emphorini sp. 1 & $\mathrm{EP}$ & & $0.15(3)$ \\
\hline \multirow[t]{2}{*}{ Ericrocidini } & Mesoplia (Mesoplia) rufipes Perty, 1833 & $\mathrm{EP}$ & $0.21(6)$ & - \\
\hline & Mesoplia (Eumelissa) frisei Perty, 1833 & $\mathrm{EP}$ & $0.07(2)$ & - \\
\hline \multirow[t]{4}{*}{ Euglossini } & Euglossa (Euglossa) cordata Linnaeus, 1758 & $\mathrm{EP}$ & $1.16(34)$ & - \\
\hline & Euglossa (Euglossa) melanotricha Moure, 1967 & $\mathrm{EP}$ & $0.10(3)$ & $13.24(269)$ \\
\hline & Eulaema (Apeulaema) nigrita Lepeletier, 1841 & $\mathrm{EP}$ & $0.41(12)$ & $0.05(1)$ \\
\hline & Exarete sp. & $\mathrm{EP}$ & - & $0.05(1)$ \\
\hline Exomalopsini & Exomalopsis (Exomalopsis) fulvofasciata Smith, 1879 & PR & $2.02(59)$ & $0.49(10)$ \\
\hline \multirow[t]{4}{*}{ Meliponini } & Friseomelitta sp. & NR & $0.03(1)$ & - \\
\hline & Paratrigona lineata Lepeletier, 1836 & PR & $0.10(3)$ & - \\
\hline & Trigona spinipes Fabricius, 1793 & NR/PR & $13.91(407)$ & $4.68(95)$ \\
\hline & Tetragonisca angustula Latreille, 1811 & PR & $0.03(1)$ & - \\
\hline Tetrapedini & Paratetrapedia sp. & PR & $0.34(10)$ & - \\
\hline \multirow[t]{2}{*}{ Xylocopini } & Ceratina (Crewella) sp. & PR & $1.09(32)$ & $2.02(41)$ \\
\hline & Xylocopa sp. & $\mathrm{EP} / \mathrm{NR}$ & $0.07(2)$ & $0.05(1)$ \\
\hline Rhathymini & Rhatymus sp. & $\mathrm{EP} / \mathrm{NR}$ & - & $1.23(25)$ \\
\hline \multicolumn{5}{|l|}{ Halictidae } \\
\hline & sp. 1 & PR & $0.03(1)$ & $0.05(1)$ \\
\hline & sp. 2 & PR & - & $0.05(1)$ \\
\hline & sp. 3 & PR & - & $0.44(9)$ \\
\hline Total & & & $27.38(801)$ & $78.54(1596)$ \\
\hline
\end{tabular}

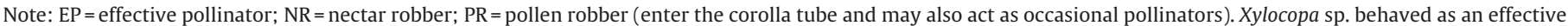
pollinator in the flowers of A. nodosum and as a nectar robber in A. peregrinum.

Table 3

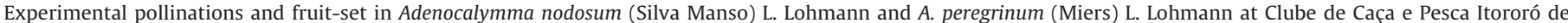
Uberlândia (CCPIU) and at Campo Alegre farm, Uberlândia City, Minas Gerais State, Brazil.

\begin{tabular}{|c|c|c|c|c|c|c|c|c|}
\hline \multirow{3}{*}{$\begin{array}{l}\text { Species/Population } \\
\text { Experimental pollinations }\end{array}$} & \multicolumn{2}{|c|}{$\begin{array}{l}\text { Adenocalymma nodosum } \\
\text { (CCPIU) }\end{array}$} & \multicolumn{6}{|c|}{ Adenocalymma peregrinum } \\
\hline & \multirow[b]{2}{*}{$\begin{array}{l}\text { Number of } \\
\text { flowers }\end{array}$} & \multirow[b]{2}{*}{$\begin{array}{l}\text { Number of } \\
\text { fruits (\%) }\end{array}$} & \multicolumn{2}{|c|}{ Campo Alegre farm } & \multicolumn{2}{|l|}{ CCPIU } & \multicolumn{2}{|l|}{ Total } \\
\hline & & & $\begin{array}{l}\text { Number of } \\
\text { flowers }\end{array}$ & $\begin{array}{l}\text { Number of } \\
\text { fruits (\%) }\end{array}$ & $\begin{array}{l}\text { Number of } \\
\text { flowers }\end{array}$ & $\begin{array}{l}\text { Number of } \\
\text { fruits (\%) }\end{array}$ & $\begin{array}{l}\text { Number of } \\
\text { flowers }\end{array}$ & $\begin{array}{l}\text { Number of } \\
\text { fruits (\%) }\end{array}$ \\
\hline Hand self-pollination & 95 & $0(0)$ & 61 & $0(0)$ & 142 & $2(1.41)$ & 203 & $2(0.98)$ \\
\hline Intraspecific hand cross-pollination & 89 & $35(39)$ & 59 & $8(13.56)$ & 205 & $62(30.24)$ & 264 & $70(26.51)$ \\
\hline Spontaneous self-pollination & 92 & $1(1.09)$ & 64 & $0(0)$ & 41 & $0(0)$ & 105 & $0(0)$ \\
\hline Emasculated flowers & 84 & $0(0)$ & 73 & $0(0)$ & 40 & $0(0)$ & 113 & $0(0)$ \\
\hline Natural pollination & 81 & $5(6)$ & 62 & $0(0)$ & 77 & $2(2.60)$ & 139 & $2(1.44)$ \\
\hline Interspecific hand cross-pollination & 114 & $40(35.09)$ & - & - & 63 & $24(38.09)$ & 63 & $24(38.09)$ \\
\hline
\end{tabular}


post-hoc comparisons the data were adjusted to either linear or higher order polynomial models. We used this approach since a full interaction analysis would not be biologically meaningful and did not show any clear pattern. We adjusted the data for ovary area to polynomial models whenever previous analyses with others traditional post-hoc tests did not show biologically meaningful patterns. We compared the ovary area between pollination treatments only $120 \mathrm{~h}$ after pollination, using in this case the Least Significant Difference test. The analyses were carried out using SPSS 17.0, GLzM module with test Type III (SPSS, Inc., Chicago, IL, USA).

Fruit maturation was monitored for three to four months after the last experimental pollination. Developed fruits from experimental and natural pollinations were collected and the number of seeds per fruit was evaluated. In order to compare the mean number of seeds per fruit among treatments, we used generalized linear models with Poisson loglinear distribution and post-hoc comparisons were made with Least Significant Difference. Seed-set was calculated based on the mean ovule number per ovary and the mean seed number per fruit. The presence or absence of an embryo was also recorded for seeds of each treatment. Comparisons of seed-set and the percentage of seeds with embryo among treatments were done with generalized linear models using a binary logistic distribution, and post-hoc comparisons were made with Least Significant Difference. Those analyses were done with the statistical package SPSS 17.0, GLzM module with test Type III (SPSS, Inc., Chicago, IL, USA).

Since our interspecific hand pollinations did set fruits, we analysed seed viability to verify if viable hybrids were formed. Seeds were sown in Gerbox ${ }^{\circledR}$ plastic boxes on cotton and filter paper moistened with distilled water, and kept at room temperature (about $25^{\circ} \mathrm{C}$ ) and natural light. Seeds were considered germinated when the radicle protruded. Seedlings were transferred to cellularized polystyrene trays, in a 1:1 mixture of Plantmax ${ }^{\circledR}$ and vermiculite substrate (expansion volume of $0.1 \mathrm{~m}^{3}$ ) to observe the subsequent seedling development. Trays were kept in greenhouse (mean temperature about $25^{\circ} \mathrm{C}$ ) under natural light conditions and moistened when necessary.

\section{Results}

\subsection{Floral biology}

Adenocalymma peregrinum flowered from December to April and A. nodosum from March to June, and both showed a few flowers open per day ("steady state" flowering pattern sensu Gentry, 1974a). The flowering periods of the species were similar in the studied areas. The overlap between flowering seasons of the species at CCPIU was observed mostly in March of 2007 and 2008. This overlap was observed during a month or even a bit more, when the interspecific hand pollinations were done. The floral events of the two species were similar, showing the corolla completely opened, profuse scent and nectar production, sensitive stigma, and pollen presentation between 9:00 and 10:00 h in the morning (Table 1). The anthers became dark and devoid of pollen grains, which fell down in the corolla tube, about 13:00 and 14:00 $\mathrm{h}$ in the afternoon, indicating the end of the pollen presentation period (Table 1). The anthesis lasted about $24 \mathrm{~h}$, when the corolla withered and lost its color and scent (Table 1 ), although many corollas abscised before withering. Pollen viability estimates were high (78-95\%) for both species, but $A$. peregrinum presented about $20 \%$ less viable pollen than $A$. nodosum at CCPIU (Table 1 ).

Nectar production patterns differed between species (Fig. 2). Adenocalymma nodosum showed ca. $33 \mu$ l of accumulated nectar with ca. $22 \%$ sugar concentration at the end of the afternoon $(17: 00 \mathrm{~h})$ with an increase in nectar volume along the time inter- vals, but no marked variation in nectar concentration (Fig. 2A, B). A. peregrinum produced $\mathrm{ca}$. $25 \mu \mathrm{l}$ with a sugar concentration of $\mathrm{ca}$. $19 \%$. However, among the 36 flowers analysed for nectar features in A. peregrinum, 13 (36\%) did not produce nectar, and in the third interval of analysis, we did not find any flowers presenting nectar. Nevertheless, for the flowers that did have nectar, A. peregrinum showed no significant variation in nectar volume and a significant increase in nectar concentration from the first to the second time interval (Fig. 2C, D). The coefficients of variation for A. nodosum were $48.25 \%, 34.87 \%$ and $53.21 \%$ for nectar volume and $13.25 \%$, $12.69 \%$ and $14.97 \%$ for nectar concentration in the 1 st, 2 nd and 3rd time intervals, respectively. While the coefficients of variation for A. peregrinum were $75.43 \%$ and $90.01 \%$ for nectar volume and $65.03 \%$ and $41.87 \%$ for nectar concentration in the 1 st and 2 nd time intervals, respectively.

\subsection{Floral visitors}

Adenocalymma peregrinum showed more than the double of visits by bees at Campo Alegre farm than A. nodosum at CCPIU, mostly due to the abundant visits of the nectar thieving bee Oxaea flavescens to the first species (Table 2). The visitation frequency was constant during the morning, declining in the end of the afternoon for both species (data not shown). Nectar robbers showed the highest frequency of visits for the two species, with $63.9 \%$ of visits in A. nodosum and $77.8 \%$ in A. peregrinum (Table 2). In the first species, the prevalent nectar robber was Trigona spinipes, and in the second species, 0 . flavescens (Table 2, Fig. 3A). Pollen robbers, which may also act as occasional pollinators, were more frequent in $A$. nodosum, with $18.8 \%$ of visits, than in A. peregrinum, with $4.3 \%$ of the visits, being represented by Ceratina (Crewella) sp., $T$. spinipes, Exomalopsis fulvofasciata and Apis mellifera (Table 2). The pollen robbers frequently opened the corolla in pre-anthesis buds (Fig. 3A, B). They made long visits to a same flower, usually walking around the anthers collecting pollen. They may occasionally touch the stigma. The pollen robbers frequently exhaust the pollen grains during their visits, making the pollen scarce during the rest of the day.

Effective pollinators for both species were medium to large bees. The frequency of visits by effective pollinators was similar between the two species, with $17.2 \%$ of the visits in A. nodosum and $17.7 \%$ in $A$. peregrinum (Table 2). In A. nodosum, the most frequent bees showing the behaviour of effective pollinators were Centris fuscata and Euglossa cordata (Fig. 3C), while in A. peregrinum were Euglossa melanotricha and Epicharis bicolor. Although E. cordata and E. melanotricha (that are about $0.4 \mathrm{~cm}$ dorsi-ventrally wide) performed a great amount of visits showing the behaviour of effective pollinators, the wide dorsiventral opening of corolla tubes, $0.57 \pm 0.11 \mathrm{~cm}$ in A. nodosum $(\mathrm{n}=7)$ and $0.82 \pm 0.17 \mathrm{~cm}$ in A. peregrinum $(\mathrm{n}=28)$, sometimes hindered the contact of these bees with the stigma (Fig. 3C). In this sense, E. cordata and E. melanotricha were less effective pollinators than the larger Centridini bees. Due to their size, Centridini bees were probably the most effective pollinators of both Adenocalymma species.

\subsection{Breeding system and interspecific pollination}

Breeding system results indicated that both species are selfsterile (Table 3), with a very small number of fruits formed after either spontaneous or hand self-pollination. The pollen-ovule ratio of $4.2 \times 10^{3}$ and $4.6 \times 10^{3}$ (Table 1 ) included the species and populations in the obligate xenogamy category (sensu Cruden, 1977), supporting the results found in experimental pollinations (Table 3 ). In the first analysis of fruit development after pollination experiments, all pistils of hand-self pollinations had been aborted 45 days after pollination in $A$. nodosum, and there were only two developing 

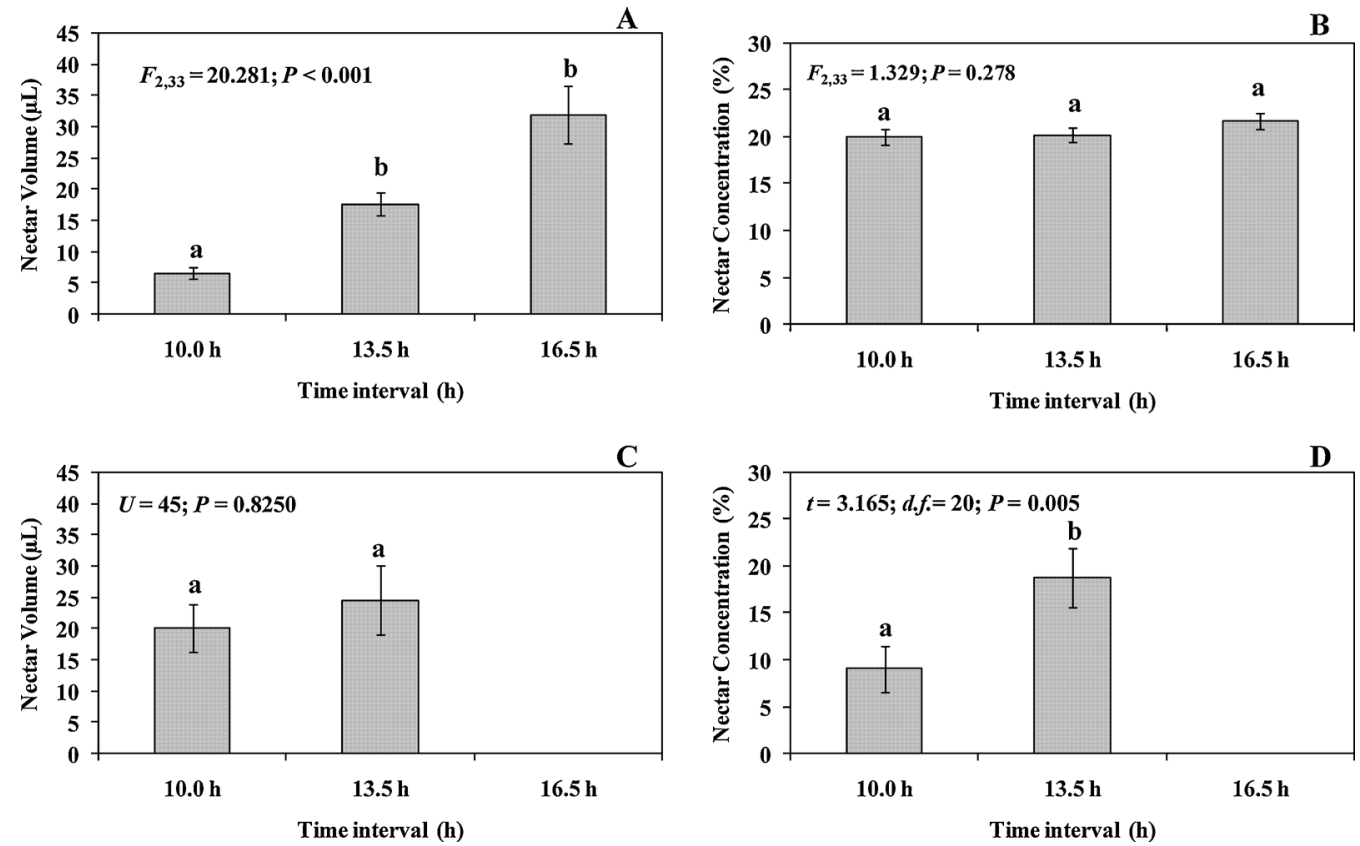

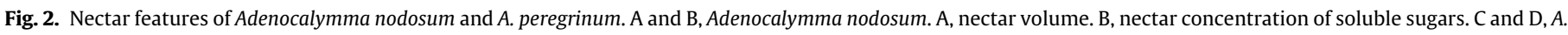

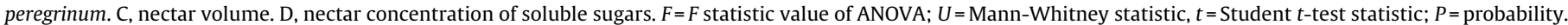
In each chart, means followed by different letters are statistically different $(P<0.05)$.

Table 4

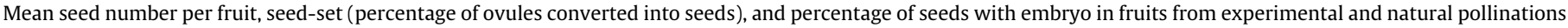
of Adenocalymma nodosum (Silva Manso) L. Lohmann and A. peregrinum (Miers) L. Lohmann.

\begin{tabular}{|c|c|c|c|c|c|c|}
\hline \multirow{2}{*}{$\begin{array}{l}\text { Species } \\
\text { Experimental pollinations }\end{array}$} & \multicolumn{3}{|c|}{ Adenocalymma nodosum } & \multicolumn{3}{|c|}{ Adenocalymma peregrinum } \\
\hline & $\begin{array}{l}\text { Mean seed } \\
\text { number per } \\
\text { fruit } \pm S D(n)\end{array}$ & Seed-set\% & $\begin{array}{l}\% \text { of seeds with } \\
\text { embryo }(n)\end{array}$ & $\begin{array}{l}\text { Mean seed } \\
\text { number per } \\
\text { fruit } \pm S D(n)\end{array}$ & Seed-set\% & $\begin{array}{l}\% \text { of seeds with } \\
\text { embryo }(n)\end{array}$ \\
\hline Hand self-pollination & - & & - & $6.00(1)$ & 42.67 & $0.00(1)$ \\
\hline Intraspecific hand cross-pollination & $8.00 \pm 2.12(26) a$ & $80.00 a$ & $83.57(35) a$ & $6.70 \pm 3.67(53) b$ & $47.52 b$ & $84.45(328) a$ \\
\hline Interspecific hand pollination & $7.68 \pm 2.94(40) a$ & $76.75 a$ & $75.88(257) b$ & $7.20 \pm 3.78(20) a b$ & $51.06 \mathrm{ab}$ & $55.91(93) \mathrm{c}$ \\
\hline Natural pollination & $6.27 \pm 2.96(49) b$ & $62.65 b$ & $66.15(65) b$ & $7.95 \pm 2.72(63) a$ & $56.42 \mathrm{a}$ & 74.49 (196)b \\
\hline Wald Chi-square $(P)$ & $9.50(P<0.01)$ & $32.77(P<0.01)$ & $5.96(P=0.05)$ & $3010.46(P<0.01)$ & $12.99(P<0.01)$ & $31.69(P<0.01)$ \\
\hline
\end{tabular}

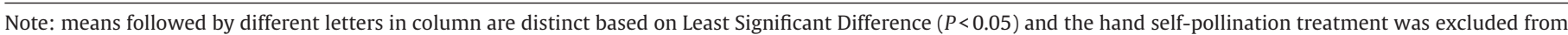
the analyses.

fruits from this treatment in A. peregrinum 20 days after pollination. Although one fruit from spontaneous self-pollination developed in A. nodosum and two of hand self-pollination developed in A. peregrinum (Table 3 ), the ISI was 0.028 for the first species and 0.037 for the second. In addition, the only fruit from hand self-pollination that reached maturity showed all seeds without embryos (Table 4).

Natural fruit-set was low (ranging between 1.4 and 6.0\%), while fruit-set from cross-pollinations was higher in both species (ranging between 26 and 39\%), leading to low reproductive efficacy in A. nodosum (0.15) and A. peregrinum (0.05) (Table 3 ). Fruit-set from interspecific hand pollinations was also high (ranging between 35 and $38 \%$ ).

Fifty per cent of the pistils from self- and $67 \%$ from crosspollinations of $A$. nodosum and $40 \%$ of the pistils of both treatments of $A$. peregrinum presented pollen tubes in the style, reaching the ovary and initiating ovule penetration $24 \mathrm{~h}$ after pollination (Fig. 3D). No differences in pollen tube growth or evidences of tube arresting mechanisms were observed in either species.

In $A$. nodosum, ovary area did not differ among treatment, but increased along time intervals. This increase was dependent on treatment (treatment: $\chi^{2}=2.44$, d.f. $=2, P=0.294$; time interval: $\chi^{2}=23.90$, d.f. $=4, P=0.002$; treatment $\times$ time interval: $\chi^{2}=62.85$, d.f. $=8, P<0.001$ ) (Fig. $4 \mathrm{~A}-\mathrm{C}$ ). The ovary area varied along time intervals for all treatments in a linear manner (cross-pollination: $\chi^{2}=60.04$, d.f. $=4, P<0.001$; self pollination: $\chi^{2}=25.89$, d.f. $=4, P<0.001$; unpollination treatment: $\chi^{2}=18.79$, d. $f .=4, P=0.001)$. However, the ovary growth rates $\left(\mathrm{mm}^{2}\right.$ per hour $)$ varied among treatments, with a rate of 0.044 for cross-, 0.028 for self-, and 0.016 for unpollinated pistils (Fig. 4A-C). Ovary areas from cross-pollinated pistils were significantly larger than those of unpollinated ones $120 \mathrm{~h}$ after pollination/onset of anthesis, but no difference was detected among ovary area for the other comparisons.

In A. peregrinum, an increase in ovary area along time intervals was detected, ovary area differed among treatments, and there was also a significant interaction effect (treatment: $\chi^{2}=28.48$, d.f. $=2, P<0.001$; time interval: $\chi^{2}=54.45$, d.f. $=4, P<0.001$; treatment $\times$ time interval: $\chi^{2}=62.85, d . f .=8, P<0.001$ ) (Fig. 4D-F). The ovary area grew along time intervals and was well adjusted to a linear regression model in cross-pollination $\left(\chi^{2}=69.91\right.$, d.f. $=4, P<0.001)$ and self-pollination $\left(\chi^{2}=21.33\right.$, d.f. $\left.=4, P<0.001\right)$ treatments. However, growth was irregular in the unpollination treatment and adjusted only to a cubic model $\left(\chi^{2}=15.98\right.$, d.f. $=4$, $P=0.003)$. The ovary growth rates $\left(\mathrm{mm}^{2}\right.$ per hour $)$ varied among 

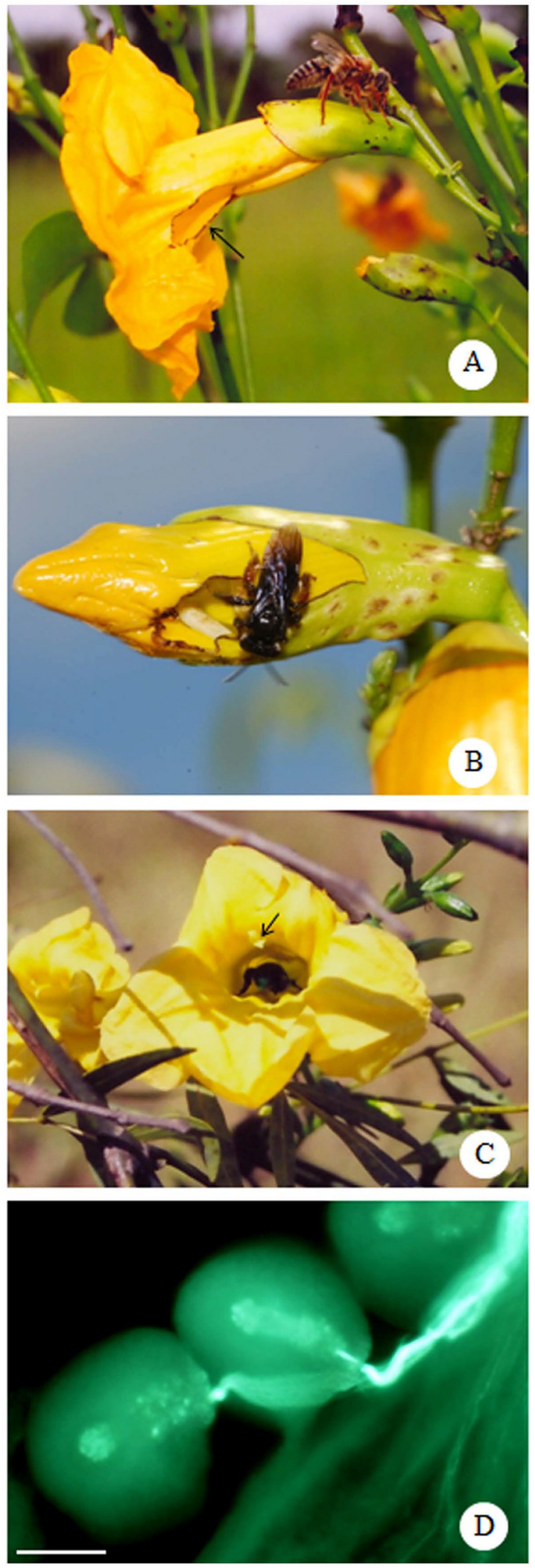

Fig. 3. Flower visitors and fertilization in Adenocalymma. A, Oxaea flavescens obtaining nectar from Adenocalymma peregrinum flower. Note that the flower had been already damaged by Trigona spinipes (arrow). B, Floral bud of $A$. peregrinum being damaged by the pollen robber $T$. spinipes. C, Euglossa cordata inside the flower of $A$. nodosum. The arrow points to the open stigma. D, Ovules from self-pollinated pistils of $A$. nodosum being penetrated by pollen tubes. Scale bar $=10 \mu \mathrm{m}$ (D). treatments, with a rate of 0.045 for cross-, 0.026 for self-pollination (Fig. 4D, E). Ovary areas differed among all pairwise pollination treatment comparisons $120 \mathrm{~h}$ after pollination/onset of anthesis.

Fruits from cross-pollinations and interspecific hand pollinations showed more seeds and a higher seed-set than those from natural pollinations in A. nodosum, whereas in A. peregrinum fruits from natural pollinations showed more seeds and a higher seed-set than those from intraspecific hand pollinations (Table 4). Seedset values were higher in $A$. nodosum than A. peregrinum in all treatments (Table 4). For both species the percentage of seeds with embryo was higher in intraspecific hand cross-pollinations than in the other treatments, and in A. peregrinum it was higher in natural pollinations than in interspecific hand pollinations (Table 4). Seed germination from interspecific pollinations ceased 40 days after sowing and all germinated seeds presented only one seedling. Among the seeds developed in A. nodosum with $A$. peregrinum as pollen donor, $88.5 \%(\mathrm{n}=87)$ germinated, and among seeds developed in $A$. peregrinum with $A$. nodosum as pollen donor 88.3\% $(n=48)$ germinated. Sixty-six days after being transferred to the greenhouse, seedlings already showed one or two pairs of leaves.

\section{Discussion}

Adenocalymma nodosum and A. peregrinum were self-sterile (sensu Bullock, 1985) but presented pollen tube growth to the ovary and ovule penetration irrespective of treatment. This characterizes a late-acting self-incompatibility system, LSI, the only self-incompatibility mechanism reported so far for Bignoniaceae (e.g. Gibbs, 1990, 2014; Gibbs and Bianchi, 1993, 1999; Bittencourt and Semir, 2005, 2006; Gandolphi and Bittencourt, 2010; Bittencourt et al., 2011). The low natural fruit-set and reproductive success in both species may be related to pollen limitation or ovule discounting (Barrett, 2002). This low natural fruit-set is not caused by interspecific pollination interference, since fruit-set after interspecific pollinations was high and the ensuing high percentages of seed germination and viable seedlings indicated a bilateral compatibility between $A$. nodosum and A. peregrinum. This general discussion is detailed below.

Although these species presented a very similar floral and pollination biology, they showed distinct patterns of nectar production. In $A$. nodosum flowers, a constant increase of nectar volume with no variation in concentration was observed, allowing visits along the anthesis, as reported for other Bignoniaceae shrub species (e.g. Milet-Pinheiro and Schlindwein, 2009). On the other hand, A. peregrinum showed a different pattern, with no variation in nectar volume and an increase in concentration, many nectarless flowers and coefficients of variation much higher than those observed for $A$. nodosum. Nectarless flowers or low nectar production may reduce attraction and would explain the lower fruit-set in A. peregrinum. However, visitation rate by effective pollinators was not different between studied species. Actually variation in floral resources may induce bees' movement among flowers and even favour outcrossing (Feinsinger, 1978; Ishii et al., 2008), though it did not reflect in a higher natural fruit-set in $A$. peregrinum.

The low natural fruit-set and reproductive success may be associated to the large number of nectar and pollen robbers in both species. The prevalence of nectar robbers in both species decreases the amount of nectar available for pollinators and may have an impact on fruit-set, as observed in other Bignoniaceae (MiletPinheiro and Schlindwein, 2009). Pollen robbers may have an even more direct impact, reducing the amount of pollen early in the morning and making it scarce for effective cross-pollinations during the rest of the day (Guimarães et al., 2008). In addition, even when they occasionally act as pollinators, they seem to perform 
A

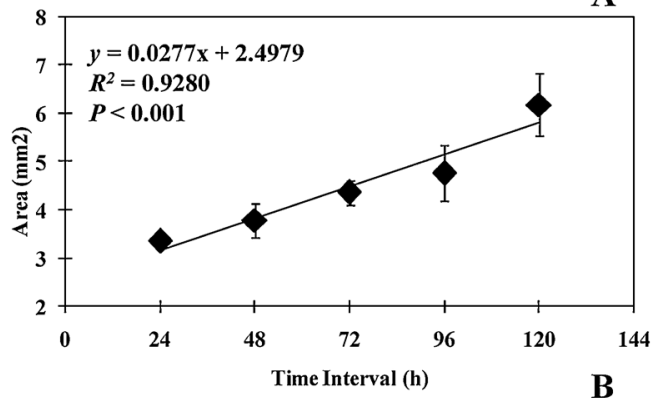

B

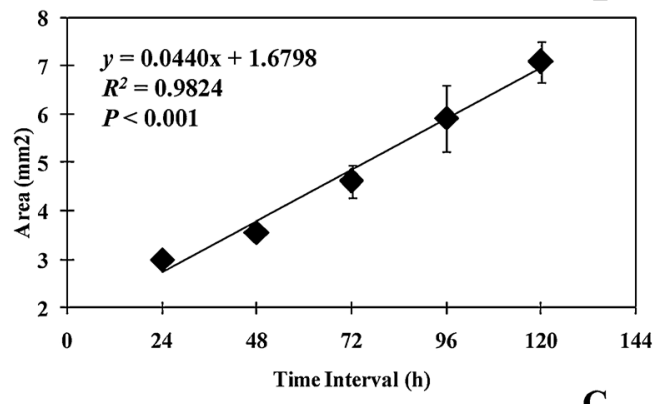

C

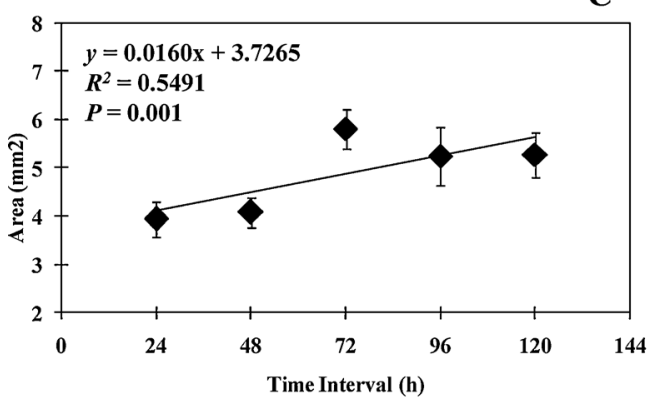

D
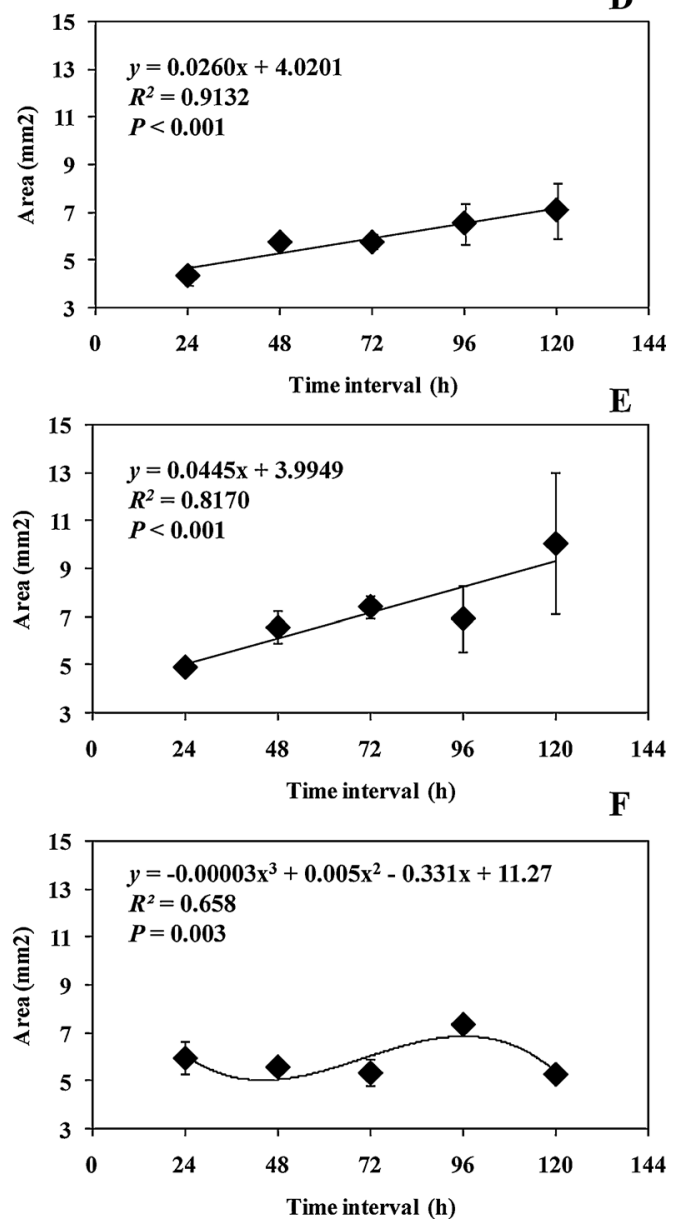

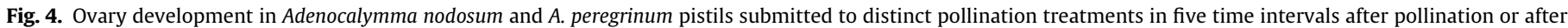

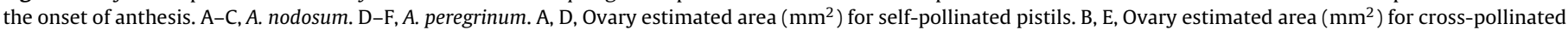

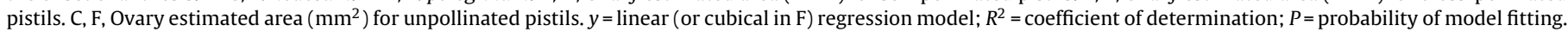

mostly self-pollinations (Guimarães et al., 2008; Milet-Pinheiro and Schlindwein, 2009).

Although quantitative studies of flower visitors were carried out in different areas and timing, which may explain the different species of effective pollinators, $A$. nodosum and A. peregrinum share the same pollinator guild of medium to large sized Centridini and Euglossini bees. Centridini bees seem to be the main pollinators also for other Adenocalymma species such as A. bracteatum (Cham.) DC. (Amaral, 1992). Xylocopa species, which are often reported as nectar robbers in Bignoniaceae flowers of Anemopaegma type (Correia et al., 2005; Dutra and Machado, 2001; Millet-Pinheiro and Schlindwein, 2009; Ynagizawa and Maimoni-Rodella, 2007), can also act as effective pollinators of Adenocalymma marginatum (Cham.) DC. (Amaral, 1992), A. bracteatum (Almeida-Soares et al., 2010) and $A$. nodosum, probably due to the wider corolla tube when compared to flowers of the other genera.

The pollen tube growth and ovule penetration in self-pollinated pistils with their posterior abscission indicate the action of LSI (Seavey and Bawa, 1986), as described for most Bignoniaceae studied so far (e.g. Gibbs and Bianchi, 1993, 1999; Bittencourt and Semir, 2005, 2006; Gandolphi and Bittencourt, 2010; Bittencourt et al., 2011). But pollen tube growth alone does not allow us to rule out early inbreeding depression processes (Gibbs, 2014). Consistently higher growth rates of ovaries after cross-pollinations in both species indicate that this may be the differential threshold avoiding pistil abortion. Similar differences in ovules and pistil development have been described for other LSI species (e.g. Gibbs et al., 1999), even with the unexpected residual growth of unpollinated pistils also observed in A. nodosum. The ovary growth rates were much higher in cross- than in self-pollinated pistils, pointing out to a delay in ovary growth in self-pollinated ones, which evidence the action of LSI in the first hours after pollination (Bittencourt and Semir, 2005, 2006; Gandolphi and Bittencourt, 2010; Bittencourt et al., 2011). The fact that $99 \%$ of selfed pistils were aborted up to 20 or 45 days after pollination in A. peregrinum and A. nodosum, respectively, also corroborates the action of a LSI, which is related to a synchronized abortion of these pistils (Bittencourt and Semir, 2005, 2006; Gandolphi and Bittencourt, 2010; Bittencourt et al., 2011). However, the development of embryoless seeds in the single developed self-pollinated fruit, as also reported to Handroathus serratifolius (Vahl) S. Grose (Alves et al., 2013), was somewhat distinct from the mostly synchronous abortion postulated for LSI species (Bittencourt et al., 2003; Bittencourt and Semir, 2005, 2006; Gandolphi and Bittencourt, 2010). However, since the fruit set from self-pollination was rare ( $1 \%$ of self-pollinated flowers), it may represent more a case of failure of LSI mechanism than an evidence of inbreeding depression.

Low natural fruit-set and reproductive success in the studied species seem to be related to pollen limitation, due to pollen robbers, or ovule discounting (sensu Barrett, 2002). Ovule discounting is the loss of ovules and pistils due to self- or mixed pollinations (i.e. mixed loads of cross and self-pollen deposited on the same stigma) that are frequent in plants with bisexual flowers that opened more than one flower per day (Kalisz et al., 2004; Bianchi et al., 2005; 
Goodwillie et al., 2005). Although we did not directly observe pollen deposition and pollen tube growth after natural pollination, the higher seed-set and seed number in fruits from cross-pollinations in $A$. nodosum evidence a higher pollen quality or quantity in those than in natural pollinations. It can be explained because in natural conditions mixed pollinations often occur, and the self-fertilized ovules may be unable to develop into seeds due to LSI action, although pistils may develop into fruits when there is a greater amount of cross-fertilized ovules (Bertin et al., 1989; Gibbs et al., 2004). However, in A. peregrinum the seed number and the seedset were higher in natural pollinations, which is more difficult to explain. The general lower seed-set recorded for $A$. peregrinum when compared with $A$. nodosum can be caused by embryo sac malformations or other reproductive problems, but this speculation has to be further investigated by histological analysis.

The fact that interspecific hand pollinations presented more seeds without embryos than intraspecific hand pollinations for both species, evidence that some interspecific fertilizations were unable to form viable embryos, and this could be another source of ovule discount in natural pollinations. Nevertheless, our data showed a bilateral compatibility between $A$. peregrinum and $A$. nodosum with seeds and seedlings developed without problems. As the speciation in Bignoniaceae seems to be predominantly allopatric (Gentry, 1980, 1990), we would expect stronger barriers maintaining the reproductive isolation among congeneric species in a community (Gentry, 1976; Amaral, 1992; Ynagizawa and Maimoni-Rodella, 2007; Zjhra, 2008). However, since in the absence of fire there is usually a temporal separation between $A$. peregrinum and $A$. nodosum flowering seasons in the region (D. Sampaio personal observation) functioning as a reproductive barrier among these species, interspecific pollen flow may be rare and would explain the absence of incompatibility mechanisms maintaining species boundaries. We could speculate that increase in fire frequency due to human disturbance (Hoffmann and Moreira, 2002) may have increased flowering overlap and favours natural hybridization.

\section{Acknowledgements}

This work was part of the Doctoral Thesis of the first author in the Post-Graduate Program of Ecology and Conservation of Natural Resources at Universidade Federal de Uberlândia UFU, supported by a research fellowship from Coordenação de Aperfeiçoamento de Pessoal de Nível Superior (CAPES). This work was also supported by research grants by Conselho Nacional de Desenvolvimento Científico e Tecnológico (CNPq) (486091/20074) and by CAPES (Programa Nacional de Pós-Doutorado - PNPD 23038.008068/2010-95). We thank administration of Clube de Caça e Pesca Itororó de Uberlândia, as administration of Campo Alegre farm for permissions to carry out the study in these areas; Dra. Lúcia G. Lohmann (Universidade de São Paulo - USP) for plants identification; Dr. Léo Correia da Rocha Filho (USP), Dra. Cláudia Inês Silva (USP), and Dra. Solange Cristina Augusto (UFU) for bees identification; Msc. Thatiana Martins dos Santos Mesquita for the help with nectar measurements of A. peregrinum; Dra. Júlia YamagishiCosta (UFU) for critical reading of the manuscript; and Natanael Nascimento dos Santos for illustrations.

\section{References}

Almeida-Soares, S., Polatto, L.P., Dutra, J.C.S., Torezan-Silingardi, H.M., 2010 Pollination of Adenocalymma bracteatum (Bignoniaceae): floral biology and visitors. Neotrop. Entomol. 39, 941-948.

Alves, M.F., Duarte, M.O., Oliveira, P.E., Sampaio, D.S., 2013. Self-sterility in the hexaploid Handroanthus serratifolius (Bignoniaceae), the national flower of Brazil. Acta Bot. Bras. 27, 714-722.
Alves, M.F., Duarte, M.O., Bittencourt, N.S., Oliveira, P.E., Sampaio, D.S., 2016. Sporophytic apomixis in polyembryonic Handroanthus serratifolius (Vahl) S. Grose (Bignoniaceae) characterizes the species as an agamic polyploid complex. Plant Syst. Evol., http://dx.doi.org/10.1007/s00606-016-1291-9 (in press).

Amaral, M.E.C., 1992. Ecologia Floral De Dez Espécies Da Tribo Bignonieae (Bignoniaceae), Em Uma Floresta Semi-decídua No Município De Campinas, SP. Doctoral Thesis. Universidade Estadual de Campinas, Campinas, Brazil

Barrett, S.C.H., 2002. Sexual interference of the floral kind. Heredity 88, 154-159.

Bertin, R.I., Barnes, C., Guttman, S.I., 1989. Self-sterility and cryptic self-fertility in Campsis radicans (Bignoniaceae). Bot. Gaz. 150, 397-403.

Bianchi, M.B., Harris, S.A., Gibbs, P.E., Prado, D.E., 2005. A study of the mating system in Dolichandra cynanchoides (Bignoniaceae): an Argentinian Chaco woodlands liana with a late-acting self-incompatibility. Plant Syst. Evol. 251, $173-181$.

Bittencourt, N.S., Moraes, C.I.G., 2010. Self-compatibility and polyembryony in South American yellow trumpet trees (Handroanthus chrysotrichus and $H$. ochraceus: Bignoniaceae): a histological study of post-pollination events. Plant Syst. Evol. 288, 59-76.

Bittencourt, N.S., Semir, J., 2005. Late-acting self-incompatibility and other breeding systems in Tabebuia (Bignoniaceae). Int. J. Plant Sci. 166, 493-506.

Bittencourt, N.S., Semir, J., 2006. Floral biology and late-acting self-incompatibility in Jacaranda racemosa (Bignoniaceae). Aust. J. Bot. 54, 315-324.

Bittencourt, N.S., Gibbs, P.E., Semir, J., 2003. Histological study of post-pollination events in Spathodea campanulata beauv. (Bignoniaceae): a species with late-acting self-incompatibility. Ann. Bot. 91, 827-834

Bittencourt, N.S., Pereira, E.J., São-Thiago, P.S., Semir, J., 2011. The reproductive biology of Cybistax antisyphilitica (Bignoniaceae), a characteristic tree of the South American savannah-like Cerrado vegetation. Flora 206, 872-886.

Bullock, S.H., 1985. Breeding systems in the flora of a tropical deciduous forest in Mexico. Biotropica 17, 287-301.

Correia, M.C.R., Pinheiro, M.C., Lima, H.A., 2005. Biologia floral e polinização de Arrabidaea conjugata (Vell.) Mart. (Bignoniaceae). Acta Bot. Bras. 19, 501-510.

Cruden, R.W., 1977. Pollen-ovule ratios: a conservative indicator of breeding systems in flowering plants. Evolution 31, 32-46.

Dafni, A., Kevan, P.G., Husband, B.C., 2005. Practical Pollination Ecology. Enviroquest, Cambridge.

Dutra, J.C.S., Machado, V.L.L., 2001. Entomofauna visitante de Stenolobium stans (Juss.) Seem (Bignoniaceae): durante seu período de floração. Neotrop. Entomol. 30, 43-53.

Feinsinger, P., 1978. Ecological interactions between plants and hummingbirds in a successional tropical community. Ecol. Monogr. 48, 269-287.

Firetti-Leggieri, F., Lohmann, L.G., Alcantara, S., Costa, I.R., Semir, J., 2013. Polyploidy and polyembryony in Anemopaegma (Bignonieae, Bignoniaceae). Plant Reprod. 26, 43-53.

Gandolphi, G., Bittencourt, N.S., 2010. Sistema reprodutivo do Ipê-Branco Tabebuia roseo-alba (Ridley) Sandwith. Acta Bot. Bras. 24, 840-853.

Gentry, A.H., 1974a. Flowering phenology and diversity in tropical Bignoniaceae. Biotropica 6, 64-68

Gentry, A.H., 1974b. Coevolutionary patterns in Central American Bignoniaceae. Ann. Missouri Bot. Gard. 61, 728-759.

Gentry, A.H., 1976. Bignoniaceae of southern Central America: distribution and ecological specificity. Biotropica 8, 117-131.

Gentry, A.H., 1980. Bignoniaceae - Part I (Crescentieae and Tourretieae). Flora Neotrop. Monogr. 25, 1-131.

Gentry, A.H., 1990. Evolutionary patterns in neotropical Bignoniaceae. Mem. N. Y. Bot. Gard 55, 118-129.

Gibbs, P.E., 1990. Self-incompatibility in flowering plants: a neotropical perspective. Rev. Bras. Bot. 13, 125-136.

Gibbs, P.E., 2014. Late-acting self-incompatibility -the pariah breeding system in flowering plants. New Phytol. 203, 717-734.

Gibbs, P.E., Bianchi, M.B., 1993. Post-pollination events in species of Chorisia (Bombacaceae) and Tabebuia (Bignoniaceae) with late-acting self-incompatibility. Bot. Acta 106, 64-71.

Gibbs, P.E., Bianchi, M.B., 1999. Does late-acting self-incompatibility (LSI) show family clustering? Two more species of Bignoniaceae with LST: Dolichandra cynanchoides and Tabebuia nodosa. Ann. Bot. 84, 449-457.

Gibbs, P.E., Oliveira, P.E., Bianchi, M.B., 1999. Postzygotic control of selfing in Hymenaea stigonocarpa (Leguminosae-Caesalpinioideae), a bat-pollinated tree of the Brazilian cerrados. Int. J. Plant Sci. 160, 72-78.

Gibbs, P.E., Bianchi, M.B., Ranga, N.T., 2004. Effects of self-, chase and mixed self/cross-pollinations on pistil longevity and fruit set in Ceiba species (Bombacaceae) with late-acting self-incompatibility. Ann. Bot. 94, 305-310.

Goodwillie, C., Kalisz, S., Eckert, C.G., 2005. The evolutionary enigma of mixed mating systems in plants occurrence, theoretical, explanations, and empirical evidence. Ann Rev. Ecol.Evol. Syst. 36, 47-79.

Gottsberger, G., Silberbauer-Gottsberber, I., 2006. Life in the Cerrado: a South American Tropical Seasonal Ecosystem. Reta Verlag, Ulm.

Grassi, R.F., Resende, U.M., Silva, W., Macedo, M.L.R., Butera, A.P., Tulli, E.O., Saffran, F.P., Siqueira, J.M., 2005. Estudo fitoquímico e avaliação alelopática de Memora peregrina -ciganinha -Bignoniaceae, uma espécie invasora de pastagens em Mato Grosso do Sul. Quím. Nova 28, 199-203.

Guimarães, E., Di Stasi, L.C., Maimoni-Rodella, R.C.S., 2008. Pollination biology of Jacaranda oxyphylla with an emphasis on staminode function. Ann. Bot. 102, 699-711. 
Hoffmann, W.A., Moreira, A.G., 2002. The role of fire in population dynamics of woody plants. In: Oliveira, P.S., Marquis, R.J. (Eds.), The Cerrados of Brazil: Ecology and Natural History of a Neotropical Savanna. Columbia University Press, New York, pp. 159-177.

Ishii, H.S., Hirabayashi, Y., Gaku, K., 2008. Combined effects of inflorescence architecture, display size, plant density and empty flowers on bumble bee behavior: experimental study with artificial inflorescences. Oecologia 156 $341-350$

Kalisz, S., Vogler, D.W., Hanley, K.M., 2004. Context-dependent autonomous self-fertilization yields reproductive assurance and mixed mating. Nature 430 884-886.

Kearns, C.A., Inouye, D.W., 1993. Techniques for Pollination Biologists. University Press of Colorado, Niwot.

Lohmann, L.G., 2006. Untangling the phylogeny of neotropical lianas (Bignonieae, Bignoniaceae). Am. J. Bot. 93, 304-318.

Lohmann, L.G., 2010a. Bignoniaceae in Lista De Espécies Da Flora Do Brasil. Jardim Botânico Do Rio De Janeiro [online]. Jardim Botânico do Rio de Janeiro, Rio de Janeiro, Available from: http://floradobrasil.jbrj.gov.br/reflora/floradobrasil/ FB112400 (accessed 25.04.2016)

Lohmann, L.G., 2010b. Bignoniaceae in Lista De Espécies Da Flora Do Brasil. Jardim Botânico Do Rio De Janeiro [online]. Jardim Botânico do Rio de Janeiro, Rio de Janeiro, Available from: http://floradobrasil.jbrj.gov.br/reflora/floradobrasil/ FB112409 (accessed 25.04.2016).

Lohmann, L.G., Taylor, C.M., 2014. A new generic classification of Bignonieae (Bignoniaceae). Ann. Missouri Bot. Gard. 99, 348-489.

Martin, F.W., 1959. Staining and observing pollen tubes in the style by means of fluorescence. Stain Tech. 34, 125-128

McDowell, E.M., Trump, B., 1976. Histological fixatives for diagnostic light and electron microscopy. Arch. Pathol. Lab. Med. 100, 405-414.

Milet-Pinheiro, P., Schlindwein, C., 2009. Pollination in Jacaranda rugosa (Bignoniaceae) Euglossine pollinators, nectar robbers and low fruit set. Plant Biol. 11, 131-141.
Neuffer, B., Paetsch, M., 2013. Flower morphology and pollen germination in the genus Capsella (Brassicaceae). Flora 208, 626-640.

Nunes, S.G., 1999. Ciganinha Memora Peregrina (Miers) Sandw Nova Planta Invasora De Pastagem. Embrapa Gado De Corte Divulga/ $\mathrm{N}^{\circ} 35$ [online]. Jardim Botânico do Rio de Janeiro, Rio de Janeiro, Available from: http://www.cnpgc. embrapa.br/publicacoes/divulga/GCD35.html (accessed 31.05.2014.).

Nunes, S.G., 2001. Controle De Plantas Invasoras Em Pastagens Cultivadas Nos Cerrados. Embrapa Gado de Corte, Campo Grande.

Oliveira-Filho, A.T., Ratter, J.A., 2002. Vegetation physiognomies and woody flora of the Cerrado biome. In: Oliveira, P.S., Marquis, R.J. (Eds.), The Cerrados of Brazil: Ecology and Natural History of a Neotropical Savanna. Columbia University Press, New York, pp. 91-120.

Olmstead, R.G., Zjhra, M.L., Lohmann, L.G., Grose, S.O., Eckert, A.J., 2009. A molecular phylogeny and classification of Bignoniaceae. Am. J. Bot. 96, 1731-1743.

Ruiz, T.Z., Arroyo, M.T.K., 1978. Plant reproductive ecology of a secondary decidual tropical forest. Biotropica 10, 221-230.

Sampaio, D.S., Bittencourt, N.S., Oliveira, P.E., 2013. Mating in the pseudogamic apomictic Anemopaegma acutifolium DC: another case of pseudo-self-compatibility in Bignoniaceae? Plant Biol. 15, 919-924.

Seavey, S.R., Bawa, K.S., 1986. Late-acting self-incompatibility in angiosperms. Bot. Rev. 52, 195-219.

Ynagizawa, Y.A.N., Maimoni-Rodella, R.C.S., 2007. Floral visitors and reproductive strategies in five Melittophilous species of Bignoniaceae in Southeastern Brazil. Braz. Arch. Biol. Tech. 50, 1043-1050.

Zar, J.H., 2010. Biostatistical Analysis. Prentice Hall, Englewood Cliffs-New Jersey.

Zjhra, M.L., 2008. Facilitating sympatric species coexistence via pollinator partitioning in endemic tropical trees of Madagascar. Plant Syst. Evol. 271, 157-176. 